\title{
Evaluation of Bacteria Detected in Both Urine and Open Wounds in Nursing
}

Facility Residents

\section{Bacteria Detected in Both Urine and Open Wounds}

$9{ }^{1}$ Department of Internal Medicine, Infectious Diseases Division, University of Michigan Medical

10 School, Ann Arbor, MI

${ }^{2}$ Department of Internal Medicine, Division of Geriatric and Palliative Medicine, University of

13 Michigan Medical School, Ann Arbor, MI

${ }^{3}$ Center for Clinical Management Research, Veterans Affairs Ann Arbor Healthcare System, Ann 16 Arbor, $\mathrm{MI}$

${ }^{4}$ Department of Medicine, Veterans Affairs Ann Arbor Healthcare System, Ann Arbor, MI,

${ }^{5}$ Department of Microbiology and Immunology, University of Michigan Medical School, Ann Arbor, MI

${ }^{6}$ Department of Pediatrics and Communicable Diseases, Division of General Pediatrics

University of Michigan Medical School, Ann Arbor, MI

\section{${ }^{+}$Corresponding Author:}

28 Jennifer Meddings MD, MSc

29 Associate Professor

30 Department of Internal Medicine

31 Division of General Medicine

32 Department of Pediatrics and Communicable Diseases

33 Division of General Pediatrics

34 University of Michigan

35 Ann Arbor, MI USA

36 Tel: +1 734 936-5216

37 Fax: +1 734 936-8944

38 Email: meddings@,med.umich.edu 


\section{ABSTRACT}

Nursing home residents are at a greater risk of developing pressure injuries that develop

42 into an open wound. Open wounds can be colonized with bacteria from multiple sources.

43 Emerging evidence suggests the specific composition of the open wound microbial community

44 can result in delayed wound healing and increased infection risk. Understanding the factors that

45 influence microbial colonization of open wounds, can lead to the prevention of infections. The

46 relationship between bacteria found in urine and that of open wounds, is currently unknown.

47 Recent studies have shown that nursing home residents can harbor a urinary microbiota

48 independent of symptoms and frequently experience urinary incontinence. To determine if the

49 colonization of open wounds mirrors urinary colonization, we conducted a pilot study with

50 nursing home residents, comparing bacteria present in open pressure injuries below the

51 umbilicus and urine. To identify microbial species that were present in both urine and open

52 wound at one timepoint, standard bacteriologic culture techniques followed by MALDI-TOF was

53 used as well as16S rRNA-encoding gene amplicon sequencing. In this study we found that some

54 bacteria detected in urine were also detected in open wounds in one individual at one timepoint,

55 using both culture dependent and independent techniques. Bacterial species that were more often

56 detected at both sites included Enterococcus faecalis, Proteus mirabilis, Escherichia coli, and

57 Providencia stuartii. This pilot study provides evidence that urinary colonization can mirror open wound colonization. Further studies are needed to investigate if parallel colonization of

59 these anatomical sites affect infection outcomes.

60

61

62

63

64

65 


\section{INTRODUCTION}

Chronic open non-healing wounds severely impact a person's quality of life and are estimated to impose $\$ 25$ billion on the health-care system annually within the United States (1-

71 include pressure injuries (previously known as pressure ulcers), diabetic foot ulcers, arterial

72 insufficiency ulcers, and venous leg ulcers (4-6). Pressure injuries in nursing home residents can

73 occur related to skin breakdown over boney prominences related to immobility. It is important to

74 focus on prevention of chronic wounds in this population, as the rate of wound repair and healing

75 reduces with increased age (5). Additionally, bacterial colonization in open wounds can

76 contribute to impaired wound healing $(7,8)$. Open pressure injuries in nursing home residents are

77 not only susceptible to contamination of microorganisms from the environment, which includes

78 contaminated caregivers, but also indigenous skin microorganisms can invade and become

79 pathogenic once the skin barrier is damaged (9). These factors make it important to focus efforts

80 on preventing bacterial contamination of open wounds. In order to design interventions to

81 prevent wound contamination and invasive infection, it is imperative to understand all sources of

82 possible contamination.

In older adults, urinary incontinence is common $(8,10,11)$. When all other types of

84 management and treatments for urinary incontinence fail to keep the skin dry, bladder

85 catheterization is often performed. This is particularly important when the patient has an open

86 wound in a body location, such as the sacrum, that is challenging to keep clear of urine or feces

$87(10,12-15)$. However, it is well known that indwelling urinary catheters can lead to increased

88 bacterial colonization, including colonization of antibiotic resistant organisms, and can promote

89 urinary tract infection $(14,16,17)$. Within nursing home residents, urinary tract infections are the 
most common type of infection $(18,19)$. To prevent urinary tract infections, multiple

91 recommendations regarding best approaches to catheter care have been made, including the

92 reduced use of catheters in this patient population (20-23). Recent studies confirm the presence

93 of a resident microbial community in urine from both catheterized and non-catheterized patients,

94 however, the impact of these communities on wound contamination remains unknown (24-26).

95 In this pilot study, we sought to determine if bacteria found in urine of nursing home

96 residents would also be found within open wounds. We hypothesized that open wounds located

97 between the umbilicus and mid-thigh could harbor bacteria also found in the nursing home

98 resident's urine. To address this question, we identified bacteria from urine and open wounds

99 using both culture dependent and independent methods to obtain a more complete census of the

100 bacteria present at these two anatomical sites.

101

102

103

104

105

106

107

\section{MATERIALS AND METHODS}

108 (HUM00092777). All participants (or approved decision makers) provided written informed

109 consent prior to the initiation of this investigation. Subjects enrolled in this study were nursing

110 home residents recruited from two nursing homes located in southeast Michigan. Recruitment for

111 nursing home A occurred between March 2015 - May 2016 whereas recruitment from nursing

112 home B occurred between January 2016 - May 2016. Both facilities included short and long-

113 term care beds. In order for residents to be eligible for this study they had to be a minimum of 18

114 years of age and have an open wound in the anatomical area of interest (between umbilicus and

115 mid-thigh). For the purposes of this investigation, open wounds included pressure injuries (at 
116 stages 2-4), and other open wounds with potential multiple etiologies (e.g., burns or surgical

117 incisions) that were not anticipated to have a direct connection with the gastrointestinal or

118 genitourinary tract. Nursing home residents with a closed wound (such as a stage 1 pressure

119 injury) or wounds expected to have a connection with the gastrointestinal tract and/or urinary

120 tract such as perirectal, fistula, and ostomies, were ineligible for this study. Additional criteria

121 that deemed a resident ineligible to enroll in this study included: residents who were receiving

122 end-of-life care or were anticipated to be discharged prior to the completion of the study, the

123 presence of nephrostomy tube or ileal conduit urinary diversion as a primary means of urine

124 output, or if the resident was anuric. Participants were subject to withdrawal from this study if

125 their open wound healed, was discharged or admitted to the hospital, or retracted consent prior to

126 the completion of sample collection. Patient data was collected by LM, JM, and BL and

127 included: demographics, reason for admission, wound and catheter (if applicable) information,

128 continence (fecal and urinary), functional status, mobility, relevant medical history, and

129 comorbidities.

131 Specimen Collection

132 All wound swabs were collected during regularly scheduled wound dressing changes by

133 nursing staff in order to minimalize disturbance in the healing process. Some subjects were

134 sampled at multiple timepoints. At each sampling timepoint, two wound swabs were taken using

135 the Levine method. Briefly, wound swabs were taken by twirling the end of a sterile cotton-

136 tipped applicator stick on the open wound in a one-square centimeter area for five seconds. Two

137 types of cotton swabs were used to collect samples from open wounds -BactiSwab ${ }^{\mathrm{TM}}$ (Starplex

138 Scientific, Inc, Ontario, Canada) and BactiSwab Dry ${ }^{\mathrm{TM}}$ (Remel, Lenexa, KS). BactiSwab ${ }^{\mathrm{TM}}$ was 
used to collect samples for downstream culture-dependent identification and BactiSwab Dry ${ }^{\mathrm{TM}}$

140 was used to collect samples for downstream culture-independent identification. Urine specimens

141 were collected from residents at the same sampling timepoint as wound swabs were collected.

142 Urine specimens were collected by midstream void (in residents able to void without a urinary

143 catheter) and by aseptic collection from urinary catheter and aliquoted for culture-dependent and

144 independent identification.

149 NJ), Colombia Agar with 5\% Sheep Blood (PA-254005.06, Becton-Dickinson, Franklin lakes,

150 NJ), MacConkey Agar (L007388, Becton-Dickinson, Franklin lakes, NJ), and Bile Esculin Agar

151 (dehydrated 299068, Becton-Dickinson, Franklin lakes, NJ). Plates were incubated at $35^{\circ} \mathrm{C}$ for

15224 hours. Representative bacterial colonies were picked and grown in $5 \mathrm{ml}$ of Brain Heart

153 Infusion (BHI) media for 18 hours, shaking at $37^{\circ} \mathrm{C}$ (dehydrated DF0418-17-7, Becton-

154 Dickinson, Franklin lakes, NJ). Freezer stocks were made by mixing $500 \mu 1$ of liquid culture

155 with $500 \mu$ l of glycerol (BP229-1, Fisher BioReagents, Pittsburgh, Pennsylvania) and stored at -

$15680^{\circ} \mathrm{C}$. Bacterial species were identified by streaking each freezer stock onto BHI agar (241830,

157 Becton-Dickinson, Franklin lakes, NJ) using a $1 \mu$ l disposable inoculating loop (22-031-21,

158 Fisher Scientific, Hampton, New Hampshire) and grown at $37^{\circ} \mathrm{C}$ for 24 hours. Colonies were

159 identified using Matrix-Assisted Laser Desorption Ionization - Time of Flight (MALDI-TOF)

160 analysis on a Bruker MALDI Biotyper CA System. One single colony was smeared, using the

161 blunt end of a wooden toothpick, onto a reusable polished steel target plate (MSP 96 target 
162 polished steel BC 8280800, Bruker Daltonik, Bremen, Germany). For each MALDI-TOF run,

163 two positive controls were added to the target plate, which included a Gram-negative control

164 (Escherichia coli, ATCC 25922) and a Gram-positive control (Staphylococcus aureus ATCC

165 25923). The target plate was air-dried prior to the addition of a matrix solution and formic acid

166 using the MALDI Biotyper Galaxy automated target plate preparation system (1836007 Bruker

167 Daltonik, Bremen, Germany). Analysis was performed as per manufacturer's instructions.

168 Bacterial identification was taken from the identified best match with a score value $\geq 2.00$.

173 disposable inoculating loop and grown at $37^{\circ} \mathrm{C}$ for 24 hours. A single colony was grown in $5 \mathrm{ml}$

174 of $\mathrm{BHI}$ media at $37^{\circ} \mathrm{C}$ for 18 hours, shaking. Bacteria were then harvested by centrifuging $1 \mathrm{ml}$

175 of culture for 1 minute at 10,000 rpm. Harvested pellets were added to a MASTERBLOCK 96

176 deep well microplate (780271, VWR, Radnor, Pennsylvania) for genomic DNA extraction using

177 the PowerMag Soil DNA isolation Kit (Mo Bio Laboratories, Inc., Cardlsbad, CA). Automated

178 isolation was performed using an EpMotion 5075 instrument (Eppendorf, Hamburg, Germany).

179 In some cases, genomic DNA was isolated by hand using the DNeasy Blood and Tissue Kit

180 (69504, Qiagen, Venlo, Limburg, Netherlands). Molecular identification was completed by

181 sequence analysis the $16 \mathrm{~S}$ rRNA-encoding gene. One $\mu$ l of extracted genomic DNA (1 - 20

$182 \mathrm{ng} / \mu \mathrm{l})$ was amplified in a $20 \mu \mathrm{l}$ reaction that contained: $11.85 \mu \mathrm{l}$ of ultra-pure DNase/RNase free

183 distilled water (10977023, Invitrogen, Walthan, Massachusetts); $2 \mu 1$ of 10x AccuPrime PCR

184 Buffer II (12346-086, Invitrogen, Walthan, Massachusetts); $4 \mu \mathrm{M}$ of forward primer (27F, 5' 

adding $0.25 \mu \mathrm{l}$ of ExoSAP-IT (78250, Affymetrix, Santa Clara, California) to $3.25 \mu$ l of ultra-

192 pure DNase/RNase free distilled water and $1.5 \mu \mathrm{l}$ of amplicon and incubated for 30 minutes at

$19337^{\circ} \mathrm{C}$ followed by 15 minutes at $80^{\circ} \mathrm{C}$. Cleaned PCR products were sent for Sanger sequencing at

194 the University of Michigan Medical School DNA Sequencing Core using nested 16S rRNA gene primers (338F, 5’ ACT CCT ACG GGA GGC AGC 3' and 907R 5' CCG TCA ATT CMT TTG AGT TT 3'). The forward and reverse reads were aligned and identification performed using the

197 Ribosomal Database Project (RDP) classifier (Release 11, Update 5, September 30, 2016) (27).

Urine and wound bacterial community analysis via 16S rRNA gene amplicon sequence analysis

201 Laboratories Inc., Cardlsbad, CA) and centrifuged for 10 minutes at 5,000 x g. The supernatant 202 was discarded, and this process was repeated using an additional $1 \mathrm{ml}$ of urine. The urine pellets 203 were then stored at $-80^{\circ} \mathrm{C}$ until processed for DNA extraction. For wound samples, the tip of the 204 wound swab was cut and placed into microcentrifuge tubes and stored at $80^{\circ} \mathrm{C}$ until processed.

205 Genomic DNA from urine and wound swabs were extracted using the MAGATTRACT

206 PowerMicrobiome DNA/RNA EP Kit (formerly known as the PowerMag Microbiome 
RNA/DNA Isolation Kit, 27500-4-EP, Mo Bio Laboratories Inc., Cardlsbad, CA) using the Eppendorf EpMotion liquid handling system.

The 16S rRNA-encoding gene from genomic DNA was amplified using barcoded dual-

210 index primers developed by Kozich et al., 2013 (28). The process used for library generation has

211 been previously described in Seekatz et al., 2015 (29). Barcoded dual-index primers specific to

212 the V4 region of the 16S rRNA gene were used for PCR amplification. PCR reactions are

213 composed of $5 \mu \mathrm{L}$ of $4 \mu \mathrm{M}$ equimolar primer set, $0.15 \mu \mathrm{L}$ of AccuPrime Taq DNA High Fidelity

214 Polymerase, $2 \mu \mathrm{L}$ of 10x AccuPrime PCR Buffer II (Thermo Fisher Scientific, catalog no.

215 12346094), $11.85 \mu \mathrm{L}$ of PCR-grade water, and $1 \mu \mathrm{L}$ of DNA template. The PCR conditions used

216 consisted of an initial denaturation $2 \mathrm{~min}$ at $95^{\circ} \mathrm{C}$, followed by 30 cycles of $95^{\circ} \mathrm{C}$ for $20 \mathrm{~s}, 55^{\circ} \mathrm{C}$

217 for $15 \mathrm{~s}$, and $72^{\circ} \mathrm{C}$ for $5 \mathrm{~min}$, with a final extention at $72^{\circ} \mathrm{C}$ for $10 \mathrm{~min}$. The DNA amplicons in

218 each PCR reaction was normalized using the SequalPrep Normalization Plate Kit (Thermo Fisher

219 Scientific, catalog no. A1051001). The normalized reactions were pooled and quantified using

220 the Kapa Biosystems Library qPCR MasterMix (ROX Low) Quantification kit for Illumina

221 platforms (catalog no. KK4873). The length of the pooled amplicons ( 399 bp) was

222 confirmedusing a high-sensitive DNA analysis kit (catalog no. 5067-4626) on an Agilent 3000

223 Bioanalyzer. Pooled amplicon library were sequenced on the Illumina MiSeq platform using the

224500 cycle MiSeq V2 Reagent kit (catalog no. MS-102-2003) according to the manufacturer's

225 instructions with modifications of the primer set with custom read 1/read 2 and index primers

226 added to the reagent cartridge. The "Preparing Libraries for Sequencing on the MiSeq" (part

227 15039740, Rev. D) protocol was used to prepare libraries with a final load concentration of 5.5

$228 \mathrm{pM}$, spiked with 15\% PhiX to create diversity within the run. DNA isolation and community 
229 sequencing was done by the University of Michigan Microbial Systems Molecular Biology

230 Laboratory.

231 Sequence data was processed and analyzed using the software package mothur (v.1.39.5)

232 and the MiSeq SOP (accessed on November 20, 2018) (28). Sequences were aligned to a

233 recreated V4 specific SILVA SEED reference (release 119) and trimmed (30). Chimeras were

234 then removed using uchime (31). Prior to calculating observed operational taxonomic units

235 (OTUs), this dataset was normalized to 7,395 sequences per sample. OTUs were then created by

236 clustering sequences based on $97 \%$ sequence similarity by the average neighbor method. OTU

237 concordance between each urine and open wound sample per timepoint was calculated using the

238 mothur calculator sharedsobs.

239 To identify the OTU classification for each bacterial cultivar, the following steps were

240 taken. First, the full length 16S sequence was generated using Sanger sequencing as described

241 above. Then, each sequence was aligned to the recreated V4 specific SILVA SEED reference

242 created for the microbiome analysis as described. Once, the V4 sequence for each cultivar was

243 identified, those sequences were aligned to the created OTUs. The output was matched to

244 specific OTUs from the community analysis.

246 Availability of data

247 Raw FASTQ files, including those for negative controls, were deposited in the SRA database 248 under BioProject ID nunmber PRJNA533783. Detailed processing steps can be found in supplemental 249 methods. 


\section{RESULTS}

Characteristics of participants involved in this pilot study

In this pilot study, a total of 13 residents from two different nursing home facilities were

257 recruited however, samples from only 9 residents were included in this study (Table 1). Four

258 residents and their samples were excluded from this analysis for not having concurrent urine and

259 wound samples. A total of 15 concurrent urine and wound samplings from 9 patients were

260 included in the analysis with 6 subjects sampled at only 1 time point and 3 subjects sampled at

261 multiple timepoints. The mean age for residents included in this analysis was 70 years old and all

262 residents were male and Caucasian. Residents enrolled in this study remained in their respective

263 nursing home for a mean of 131 days, with a range of 10-740 days. Most residents in this study

264 were described as immobile ( $\mathrm{n}=8,89 \%)$. Of those 8 residents, immobility was described to be

265 resulted from paraplegia $(n=4)$, morbid obesity $(n=2)$, and unknown $(n=2)$. A proportion of

266 residents in this study were documented as having urinary incontinence $(n=4,44 \%)$, two of

267 which also had fecal incontinence. Each resident, with the exception of resident number 8 , had

268 only one eligible open wound in the area of interest. Resident 8 had two eligible open wounds in

269 the area of interest.

271 Microbial community structure of urine and open wounds

To obtain a global view of bacteria present in urine and wound from these residents, we

273 used culture-independent analysis that involved sequence analysis of V4 region amplicons of the

274 16S rRNA gene. This method has been used to characterize the community structure of complex

275 microbial consortia from a variety of habitats. A total of 1,411,374 sequences were generated in

276 this dataset with an average of 45,528 sequences per sample $(\min =7,395 \max =141,600$ 
277 sequences per sample). This analysis revealed the presence of a multispecies bacterial

278 community in most samples (Figure 1). In general, a greater diversity of organisms was present

279 in wound samples compared to urine samples. Urine samples had a mean observed species

280 (richness) of $44.6(\min =5 ; \max =151 ;$ standard deviation $=39.96)$, compared to an average of

28174.5 for wounds samples $(\min =19 ; \max =164 ;$ standard deviation $=49)($ Supplemental Table

282 1). Residents varied with respect to the nature of the community structure in both urine and open

283 wounds. In residents who had more than one sample obtained over time, the communities at one

284 site were more similar over time compared to the communities in other residents.

285 In addition to the greater diversity observed in wound samples compared to urine, urine

286 was more likely to be characterized by the presence of one dominant OTU compared to wounds

287 (Figure 1). For example, OTU0001 (Unclassified Enterobacteriaceae) was the only type of

288 bacteria seen in urine samples from residents 1, 4 and 5 while the three urine samples from

289 resident 9 were dominated by OTU0003 (Escherichia/Shigella). In wound samples, greater

290 diversity was observed, although a minority of communities had one dominant OTU. For

291 example, resident 1 had an overabundance of OTU0005 (Acinetobacter), whereas residents 2, 5,

292 and 7 had an overabundance of OTU0002 (Pseudomonas).

294 Culture-based analysis of urine and wound specimens

295 For clinical purposes, bacterial culture has been the mainstay of microbial isolation and

296 identification. We isolated bacteria from urine and open wounds using aerobic culture on

297 standard microbiologic media and identified organisms obtained through the use of MALDI-

298 TOF (Supplemental Table 2). One hundred and eighteen bacterial isolates were obtained from 15

299 wound and 15 urine samples. These 118 isolates were identified as a total of 31 different species. 
In 12 of 15 urine samples and 15 of 15 wound samples, more than one species was identified by culture. Within urine samples, the most frequently isolated bacteria were Enterococcus faecalis, Aerococcus sanguinicola, Escherichia coli, Proteus mirabilis, and Providencia stuartii. Within open wounds, Staphylococcus and Corynebacterium species were commonly isolated from residents, as well as E. faecalis, Pseudomonas aeruginosa, and Acinetobacter baumannii. To compare the results of cultivation to the culture-independent analysis, partial 16S rRNA-encoding gene sequences were obtained from each cultivar. These partial 16S sequences were compared to the community $16 \mathrm{~S}$ data to assign each cultivar to an OTU identified by the culture-independent analysis. With two exceptions (both were cultivars identified as

310 identified by community analysis (Supplemental Table 2). For 6 of 15 urine samples, the

311 cultivated organisms were the most abundant OTUs encountered by community analysis. This

312 was comparable to open wound samples where for 5 out of 15 samples, the cultivar was the most 313 abundant OTU (Table 2).

315 Bacteria detected in both urine and open wounds per resident

We used both culture-dependent and independent methods to identify the presence of

317 bacterial species within both urine and open wounds obtained at the same time (Table 3). Using

318 bacterial culture, at least one bacterial species was detected in both urine and open wound for 13 319 out of 15 timepoints. In two cases, all bacterial species that were detected in urine were detected

320 within a resident's open wound (resident 3 sampling timepoint 1, and resident 7 sampling

321 timepoint 2). Using culture-independent characterization of the wound and urine microbiota, at

322 least 1 OUT was shared by both urine and open wounds for all 15 sampling timepoint. 
Of the 30 bacterial species isolated in at least one sample of urine or wound using

324 culture-based analysis, there were 6 bacterial species isolated from both urine and open wound at

325 the same sampling timepoint for a resident (Table 4). This included (in descending order of

326 frequency) E. faecalis, P. mirabilis, E. coli, P. stuartii, P. aeruginosa and Citrobacter farmeri.

327 Using culture-independent methods (Supplemental Table 3), the community analysis data

328 revealed that 164 OTUs were shared between urine and open wounds. The OTUs that were most

329 frequently found in both the urine and wound at the same sampling timepoint were OTU0003

330 (Escherichia/Shigella), OTU0004 (Enterococcus), OTU0031 (Bacteroides), OTU0017

331 (Anaerococcus), OTU0021 (Actinotignum), and OTU0025 (Anaerococcus).

\section{DISCUSSION}

334 In this pilot study, we assessed how often the same bacterial species was identified in

335 both the urine and open wounds from nursing home residents for specimens collected at the same

336 sampling timepoint. This was assessed for wounds located in body areas anticipated to be at high

337 risk of contamination from urine. Comparison of bacterial species identified from different

338 anatomical sources in the same patient has been evaluated previously in an effort to identify

339 possible sources of bacteremia (32), noting some organisms responsible for bloodstream

340 infections were also found in urine and wound microbiota. Additionally, concordance between

341 urinary tract infections and positive blood cultures in neonates has been previously identified

342 (33). Although it is well recognized that contamination of open wounds by microorganisms can

343 lead to infectious complications such as cellulitis, osteomyelitis, bacteremia, and delayed wound

344 healing $(5,7,34,35)$, and that urine is frequently colonized (i.e., asymptomatic bacteriuria) in

345 nursing home residents, we believe this is the first study to identify bacteria present in both urine 
346 and open wounds at the same timepoint, using both culture-dependent and culture-independent

347 methods (36).

348 In this pilot study we identified bacterial species that were present in both urine and open

349 wounds in a patient at a specific timepoint (Table 3). This finding was noted using both culture-

350 dependent and culture-independent methods. Using culture dependent methods revealed that 13

351 out of 15 timepoints indicated at least one bacterial species was present in both urine and open

352 wounds in one patient at a specific time. This is in contrast to culture-independent methods that

353 revealed OTUs were shared at all timepoints sampled. Interestingly, there were some bacterial

354 species that were found to be present in both urine and open wounds more often than other

355 bacterial species. These species included E. faecalis, P. mirabilis, E. coli, P. stuartii, P.

356 aeruginosa, and C. farmeri. This result was mirrored in our culture-independent analysis where

357 some OTUs were also found to be shared more often than others. OTUs that were found to be

358 present in both anatomical sites include OTU0003 (Escherichia/Shigella), OTU0004

359 (Enterococcus), OTU0031 (Bacteroides), OTU0017 (Anaerococcus), and OTU0021

360 (Actinotignum) (Supplemental Table 3). Overall these results indicate that bacterial colonization

361 of the urine can mirror colonization of open wounds.

362 We initially performed this study by employing standard microbiologic culture to isolate

363 organisms, and MALDI-TOF to identify those organisms, from both urine and open wounds.

364 Since standard culture methods used for diagnosis and clinical treatment are designed to

365 selectively enrich for target organisms, we sought to determine if the use of a more

366 comprehensive, less biased method to retrieve information on the bacterial communities in urine

367 and wounds would provide additional insight into the microbiota in these two anatomic sites. As

368 expected, profiling the bacteria in urine and wounds using 16S rRNA-encoding gene sequence 
analysis provided evidence for a greater diversity of organisms than that encountered using

370 culture alone (Supplemental Table 1). Organisms that were identified as the most abundant

371 pathogen using culture were a minor component of the entire community in many samples based

372 on culture-independent analysis. For example, in resident 3 at sampling timepoint 1, culture

373 dependent identification revealed that E. faecalis, E. coli, and C. farmeri were the only species

374 present in this urine specimen (Supplemental Table 2). When comparing these data to $16 \mathrm{~S}$

375 rRNA-encoding gene sequence analysis, those species compose only $10.8 \%$ of the community,

376 and the most abundant organism was found to be OTU0007 Prevotella (Table 2). In some cases,

377 culture-independent analyses identified anaerobes as the most abundant OTUs identified in a

378 given sample. This has been noted in previous studies that identified the presence of 16S genes

379 from anaerobes in chronic wounds (37). It should be noted that identification of anaerobes from a

380 sample using 16S rRNA-encoding gene sequence analysis does not indicate the presence of

381 viable organisms. It is possible that this is simply a marker of fecal contamination.

383 urine does not necessarily implicate the urine as the ultimate source of the microbes found in

384 wounds. Indeed, with mostly cross-sectional sampling, the directionality of transfer itself is not

385 known. Furthermore, we did not collect fecal samples, another potential source for

386 contamination of both urine and wound. A limitation of our analysis is we did not collect fecal

387 specimens from the residents to compare with urine and wound specimens. Indeed, some of the

388 bacteria that were identified as most often being concordant between urine and wound including

389 E. faecalis, P. mirabilis, E. coli, and P. stuartii can be found as indigenous members of the gut

390 microbiota. This observation was also observed using culture-independent identification methods

391 where we identified OTU0003 (Escherichia/Shigella), OTU0004 (Enterococcus), OTU0031 
392 (Bacteroides), OTU0017 (Anaerococcus), OTU0021 (Actinotignum), and OUT0025

393 (Anaerococcus) were the species that were most concordant.

394 Overall, this pilot study indicates that bacteria from the urine can often be found in open

395 wounds within the same patient at a point in time in nursing home residents, with or without

396 urinary catheter use, using both culture dependent and independent methods. This study

397 warrants further investigation into the role of urinary microorganisms within open wound

398 contamination. Another important consideration is that some species are found at higher

399 frequency than others, which suggest that they are more robust and can live in many

400 environments. This is of particular concern as many of these organisms can often be found to be

401 resistant to antibiotics and in some cases resistant to multiple types of antibiotics. Further

402 investigation is needed to fully understand the relationship and clinical implications of organisms

403 found in both urine and open wounds in the nursing home population. 


\section{REFERENCES}

1. Sen CK, Gordillo GM, Roy S, Kirsner R, Lambert L, Hunt TK, Gottrup F, Gurtner GC, Longaker MT. 2009. Human skin wounds: a major and snowballing threat to public health and the economy. Wound repair and regeneration : official publication of the Wound Healing Society [and] the European Tissue Repair Society 17:763-771.

2. Phillips T, Stanton B, Provan A, Lew R. 1994. A study of the impact of leg ulcers on quality of life: Financial, social, and psychologic implications. Journal of the American Academy of Dermatology 31:49-53.

3. Snyder RJ, Hanft JR. 2009. Diabetic foot ulcers--effects on QOL, costs, and mortality and the role of standard wound care and advanced-care therapies. Ostomy Wound Manage 55:28-38.

4. Beniamino P, Vadala M, Laurino C. 2016. Cross-linked hyaluronic acid in pressure ulcer prevention. J Wound Care 25:400-5.

5. Gould L, Abadir P, Brem H, Carter M, Conner-Kerr T, Davidson J, DiPietro L, Falanga V, Fife C, Gardner S, Grice E, Harmon J, Hazzard WR, High KP, Houghton P, Jacobson N, Kirsner RS, Kovacs EJ, Margolis D, Horne FM, Reed MJ, Sullivan DH, Thom S, Tomic-Canic M, Walston J, Whitney JA, Williams J, Zieman S, Schmader K. 2015. Chronic Wound Repair and Healing in Older Adults: Current Status and Future Research. Journal of the American Geriatrics Society 63:427-438.

6. Panel NPUA. NPUAP Pressure Injury Stages, p. In (ed),

7. Loesche M, Gardner SE, Kalan L, Horwinski J, Zheng Q, Hodkinson BP, Tyldsley AS, Franciscus CL, Hillis SL, Mehta S, Margolis DJ, Grice EA. 2017. Temporal stability in chronic wound microbiota is associated with poor healing. The Journal of investigative dermatology 137:237-244.

8. Thirugnanasothy S. 2010. Managing urinary incontinence in older people. Bmj 341:c3835.

9. Grice EA, Segre JA. 2011. The skin microbiome. Nature Reviews Microbiology 9:244.

10. Ouslander JG, Kane RL, Abrass IB. 1982. Urinary incontinence in elderly nursing home patients. Jama 248:1194-8.

11. Jerez-Roig J, Santos MM, Souza DLB, Amaral FLJS, Lima KC. 2016. Prevalence of urinary incontinence and associated factors in nursing home residents. Neurourology and Urodynamics 35:102-107.

12. Nambiar AK, Bosch R, Cruz F, Lemack GE, Thiruchelvam N, Tubaro A, Bedretdinova DA, Ambuhl D, Farag F, Lombardo R, Schneider MP, Burkhard FC. 2018. EAU Guidelines on Assessment and Nonsurgical Management of Urinary Incontinence. Eur Urol 73:596-609.

13. Cohn JA, Ni S, Kaufman MR, Graves AJ, Penson DF, Dmochowski RR, Reynolds WS. 2017. Urinary retention and catheter use among U.S. female Medicare beneficiaries: Prevalence and risk factors. Neurourology and Urodynamics 36:2101-2108.

14. Gould CV, Umscheid CA, Agarwal RK, Kuntz G, Pegues DA. 2015. Guideline for Prevention of Catheter-Associated Urinary Tract Infections 2009. Infection Control \&\#x0026; Hospital Epidemiology 31:319-326.

15. Meddings J, Saint S, Fowler KE, Gaies E, Hickner A, Krein SL, Bernstein SJ. 2015. The Ann Arbor Criteria for Appropriate Urinary Catheter Use in Hospitalized Medical 
Patients: Results Obtained by Using the RAND/UCLA Appropriateness Method. Ann Intern Med 162:S1-34.

16. Hooton TM, Bradley SF, Cardenas DD, Colgan R, Geerlings SE, Rice JC, Saint S, Schaeffer AJ, Tambayh PA, Tenke P, Nicolle LE. 2010. Diagnosis, Prevention, and Treatment of Catheter-Associated Urinary Tract Infection in Adults: 2009 International Clinical Practice Guidelines from the Infectious Diseases Society of America. Clinical Infectious Diseases 50:625-663.

17. Saint S, Chenoweth CE. 2003. Biofilms and catheter-associated urinary tract infections. Infectious disease clinics of North America 17:411-432.

18. Nicolle LE. 2015. Urinary Tract Infections in Long-Term-Care Facilities. Infection Control \&\#x0026; Hospital Epidemiology 22:167-175.

19. Briongos-Figuero LS, Gomez-Traveso T, Bachiller-Luque P, Dominguez-Gil Gonzalez M, Gomez-Nieto A, Palacios-Martin T, Gonzalez-Sagrado M, Duenas-Laita A, PerezCastrillon JL. 2012. Epidemiology, risk factors and comorbidity for urinary tract infections caused by extended-spectrum beta-lactamase (ESBL)-producing enterobacteria. Int J Clin Pract 66:891-6.

20. Mody L, Saint S, Galecki A, Chen S, Krein SL. 2010. Knowledge of evidence-based urinary catheter care practice recommendations among healthcare workers in nursing homes. J Am Geriatr Soc 58:1532-7.

21. Pratt RJ, Pellowe C, Loveday HP, Robinson N, Smith GW, Barrett S, Davey P, Harper P, Loveday C, McDougall C, Mulhall A, Privett S, Smales C, Taylor L, Weller B, Wilcox M. 2001. The epic project: developing national evidence-based guidelines for preventing healthcare associated infections. Phase I: Guidelines for preventing hospital-acquired infections. Department of Health (England). J Hosp Infect 47 Suppl:S3-82.

22. Pratt RJ, Pellowe CM, Wilson JA, Loveday HP, Harper PJ, Jones SR, McDougall C, Wilcox MH. 2007. epic2: National evidence-based guidelines for preventing healthcareassociated infections in NHS hospitals in England. J Hosp Infect 65 Suppl 1:S1-64.

23. Meddings J, Saint S, Krein SL, Gaies E, Reichert H, Hickner A, McNamara S, Mann JD, Mody L. 2017. Systematic Review of Interventions to Reduce Urinary Tract Infection in Nursing Home Residents. J Hosp Med 12:356-368.

24. Pearce MM, Zilliox MJ, Thomaswhite KJ, Richter HE, Nager CW, Visco AG, Nygaard I, Barber MD, Schaffer J, Moalli P, Sung VW, Smith AL, Rogers R, Nolen TL, Wallace D, Meikle SF, Gai X, Wolfe AJ, Brubaker L, for the Pelvic Floor Disorders N. 2015. The Female Urinary Microbiota in Urgency Urinary Incontinence. American journal of obstetrics and gynecology 213:347.e1-347.e11.

25. Hilt EE, McKinley K, Pearce MM, Rosenfeld AB, Zilliox MJ, Mueller ER, Brubaker L, Gai X, Wolfe AJ, Schreckenberger PC. 2014. Urine Is Not Sterile: Use of Enhanced Urine Culture Techniques To Detect Resident Bacterial Flora in the Adult Female Bladder. Journal of Clinical Microbiology 52:871-876.

26. Rampini SK, Bloemberg GV, Keller PM, Buchler AC, Dollenmaier G, Speck RF, Bottger EC. 2011. Broad-range 16S rRNA gene polymerase chain reaction for diagnosis of culture-negative bacterial infections. Clin Infect Dis 53:1245-51.

27. Wang Q, Garrity GM, Tiedje JM, Cole JR. 2007. Naive Bayesian classifier for rapid assignment of rRNA sequences into the new bacterial taxonomy. Appl Environ Microbiol 495 73:5261-7. 
28. Kozich JJ, Westcott SL, Baxter NT, Highlander SK, Schloss PD. 2013. Development of a dual-index sequencing strategy and curation pipeline for analyzing amplicon sequence data on the MiSeq Illumina sequencing platform. Appl Environ Microbiol 79:5112-20.

29. Seekatz AM, Theriot CM, Molloy CT, Wozniak KL, Bergin IL, Young VB. 2015. Fecal Microbiota Transplantation Eliminates Clostridium difficile in a Murine Model of

Relapsing Disease. Infect Immun 83:3838-46.

30. Pruesse E, Quast C, Knittel K, Fuchs BM, Ludwig W, Peplies J, Glockner FO. 2007. SILVA: a comprehensive online resource for quality checked and aligned ribosomal RNA sequence data compatible with ARB. Nucleic Acids Res 35:7188-96.

31. Edgar RC, Haas BJ, Clemente JC, Quince C, Knight R. 2011. UCHIME improves sensitivity and speed of chimera detection. Bioinformatics 27:2194-200.

32. Lee HG, Jang J, Choi JE, Chung DC, Han JW, Woo H, Jeon W, Chun BC. 2013. Blood stream infections in patients in the burn intensive care unit. Infect Chemother 45:194201.

33. Downey LC, Benjamin DK, Jr., Clark RH, Watt KM, Hornik CP, Laughon MM, CohenWolkowiez M, Smith PB. 2013. Urinary tract infection concordance with positive blood and cerebrospinal fluid cultures in the neonatal intensive care unit. J Perinatol 33:302-6.

34. Robson MC. 1997. WOUND INFECTION: A Failure of Wound Healing Caused by an Imbalance of Bacteria. Surgical Clinics of North America 77:637-650.

35. Wysocki AB. 2002. Evaluating and managing open skin wounds: colonization versus infection. AACN Clin Issues 13:382-97.

36. Nicolle LE. 2000. Urinary tract infection in long-term-care facility residents. Clin Infect Dis 31:757-61.

37. Choi Y, Banerjee A, McNish S, Couch KS, Torralba MG, Lucas S, Tovchigrechko A, Madupu R, Yooseph S, Nelson KE, Shanmugam VK, Chan AP. 2018. Co-occurrence of Anaerobes in Human Chronic Wounds. Microb Ecol doi:10.1007/s00248-018-1231-z. 
524 Table 1: Participant characteristics at first sampling timepoint

525

\begin{tabular}{|l|l|}
\hline \multicolumn{1}{|c|}{ Characteristic } & Residents (n=9) \\
\hline Demographics & 70 \\
\hline Age, mean & $9(100 \%)$ \\
\hline Male Sex, no. (\%) & $9(100 \%)$ \\
\hline $\begin{array}{l}\text { Race, no. (\%) } \\
\text { Caucasian }\end{array}$ \\
\hline \multicolumn{2}{|c|}{$131[10-740]$} \\
\hline Length of stay days, mean [range] & $8(89 \%)$ \\
\hline Mobility & $4(44 \%)$ \\
\hline Immobile & $2(22 \%)$ \\
Paraplegia & $2(22 \%)$ \\
Morbid Obesity & $4(44 \%)$ \\
Etiology not further specified & $2(22 \%)$ \\
\hline Incontinence & $2(22 \%)$ \\
\hline Incontinent & \\
Fecal and Urinary Incontinence & \\
Urinary (without Fecal) Incontinence & $3(33 \%)$ \\
\hline Method for Urine Specimen Collection & $4(44 \%)$ \\
\hline Clean Catch (no catheter use) & $2(22 \%)$ \\
Intermittent Straight Catheter (ISC) & \\
Indwelling Transurethral (Foley) Catheter & \\
\hline
\end{tabular}


528 Table 2: Abundance of cultivar identified OTUs within each sample

\begin{tabular}{|c|c|c|c|c|c|c|}
\hline & \multicolumn{3}{|c|}{ Urine } & \multicolumn{3}{|c|}{ Wound } \\
\hline $\begin{array}{l}\text { Time } \\
\text { point }\end{array}$ & $\begin{array}{l}\text { Most abundant OTU } \\
\text { in sample } \\
\text { (culture-independent } \\
\text { analysis) }\end{array}$ & $\begin{array}{l}\text { MALDI-TOF ID of } \\
\text { cultivar } \\
\text { corresponding to } \\
\text { most abundant } \\
\text { OTU }\end{array}$ & $\begin{array}{l}\text { Percentage } \\
\text { of } \\
\text { community } \\
\text { represented } \\
\text { by all } \\
\text { cultivars }\end{array}$ & $\begin{array}{l}\text { Most abundant } \\
\text { OTU in sample } \\
\text { (culture- } \\
\text { independent } \\
\text { analysis) }\end{array}$ & $\begin{array}{l}\text { MALDI-TOF ID of } \\
\text { cultivar } \\
\text { corresponding to } \\
\text { most abundant OTU }\end{array}$ & $\begin{array}{l}\text { Percentage of } \\
\text { community } \\
\text { represented } \\
\text { by all cultivars }\end{array}$ \\
\hline 1.1 & $\begin{array}{l}\text { OTU0001 } \\
\text { Enterobacteriaceae } \\
\text { unclassified }(99.9 \%)\end{array}$ & $\begin{array}{l}\text { Enterobacter } \\
\text { asburiae }\end{array}$ & $99.99 \%$ & $\begin{array}{l}\text { OTU0005 } \\
\text { Actinobacter } \\
(95 \%)\end{array}$ & $\begin{array}{l}\text { Acinetobacter } \\
\text { baumannii }\end{array}$ & $95.2 \%$ \\
\hline 2.1 & $\begin{array}{l}\text { OTU0004 } \\
\text { Enterococcus } \\
(98.0 \%)\end{array}$ & $\begin{array}{l}\text { Enterococcus } \\
\text { faecalis }\end{array}$ & $98.1 \%$ & $\begin{array}{l}\text { OTU0002 } \\
\text { Pseudomonas } \\
(86.0 \%)\end{array}$ & $\begin{array}{l}\text { Pseudomonas } \\
\text { aeruginosa }\end{array}$ & $91.7 \%$ \\
\hline 3.1 & $\begin{array}{l}\text { OTU0007 } \\
\text { Prevotella (47.2\%) }\end{array}$ & $\begin{array}{l}\text { Not captured by } \\
\text { cultivation }\end{array}$ & $10.8 \%$ & $\begin{array}{l}\text { OTU0042 } \\
\text { Lachnospiraceae } \\
\text { unclassified } \\
(18.5 \%)\end{array}$ & $\begin{array}{l}\text { Not captured by } \\
\text { cultivation }\end{array}$ & $19.9 \%$ \\
\hline 4.3 & $\begin{array}{l}\text { OTU0001 } \\
\text { Enterobacteriaceae } \\
\text { unclassified }(99.3 \%)\end{array}$ & $\begin{array}{l}\text { Klebsiella } \\
\text { pneumoniae }\end{array}$ & $99.9 \%$ & $\begin{array}{l}\text { OTU0010 } \\
\text { Prevotella } \\
(26.0 \%)\end{array}$ & $\begin{array}{l}\text { Not captured by } \\
\text { cultivation }\end{array}$ & $0 \%$ \\
\hline 5.1 & $\begin{array}{l}\text { OTU0001 } \\
\text { Enterobacteriaceae } \\
\text { unclassified }(99.7 \%)\end{array}$ & $\begin{array}{l}\text { Citrobacter } \\
\text { amalonaticus }\end{array}$ & $99.7 \%$ & $\begin{array}{l}\text { OTU0002 } \\
\text { Pseudomonas } \\
(92.0 \%)\end{array}$ & $\begin{array}{l}\text { Pseudomonas } \\
\text { aeruginosa }\end{array}$ & $99.5 \%$ \\
\hline 6.3 & $\begin{array}{l}\text { OTU0023 } \\
\text { Achromobacter } \\
(12 \%)\end{array}$ & $\begin{array}{l}\text { Not captured by } \\
\text { cultivation }\end{array}$ & $0.2 \%$ & $\begin{array}{l}\text { OTU0023 } \\
\text { Achromobacter } \\
(10.0 \%)\end{array}$ & $\begin{array}{l}\text { Not captured by } \\
\text { cultivation }\end{array}$ & $4.3 \%$ \\
\hline 7.1 & $\begin{array}{l}\text { OTU0020 } \\
\text { Corynebacterium } \\
(27.3 \%)\end{array}$ & $\begin{array}{l}\text { Corynebacterium } \\
\text { aurimucosum }\end{array}$ & $31.9 \%$ & $\begin{array}{l}\text { OTU0002 } \\
\text { Pseudomonas } \\
(65.0 \%)\end{array}$ & $\begin{array}{l}\text { Pseudomonas } \\
\text { aeruginosa }\end{array}$ & $77.0 \%$ \\
\hline 7.2 & $\begin{array}{l}\text { OTU0009 } \\
\text { Staphylococcus } \\
(22.0 \%)\end{array}$ & $\begin{array}{l}\text { Staphylococcus } \\
\text { capitis }\end{array}$ & $46.6 \%$ & $\begin{array}{l}\text { OTU0002 } \\
\text { Pseudomonas } \\
(69.2 \%)\end{array}$ & $\begin{array}{l}\text { Pseudomonas } \\
\text { aeruginosa }\end{array}$ & $73.2 \%$ \\
\hline 8.1 & $\begin{array}{l}\text { OTU0018 } \\
\text { Aerococcus (20.2\%) }\end{array}$ & $\begin{array}{l}\text { Aerococcus } \\
\text { sanguinicola }\end{array}$ & $47.6 \%$ & $\begin{array}{l}\text { OTU0011 } \\
\text { Parvimonas } \\
(32.7 \%)\end{array}$ & $\begin{array}{l}\text { Not captured by } \\
\text { cultivation }\end{array}$ & $1.0 \%$ \\
\hline 8.2 & $\begin{array}{l}\text { OTU0018 } \\
\text { Aerococcus (30\%) }\end{array}$ & $\begin{array}{l}\text { Aerococcus } \\
\text { sanguinicola }\end{array}$ & $55.0 \%$ & $\begin{array}{l}\text { OTU0011 } \\
\text { Parvimonas } \\
(30.0 \%)\end{array}$ & $\begin{array}{l}\text { Not captured by } \\
\text { cultivation }\end{array}$ & $1.7 \%$ \\
\hline 8.3 & $\begin{array}{l}\text { OTU0018 } \\
\text { Aerococcus (26.2\%) }\end{array}$ & $\begin{array}{l}\text { Aerococcus } \\
\text { sanguinicola }\end{array}$ & $38.7 \%$ & $\begin{array}{l}\text { OUT0014 } \\
\text { Providencia } \\
(31.3 \%)\end{array}$ & Providencia stuartii & $52.8 \%$ \\
\hline 8.4 & $\begin{array}{l}\text { OTU0015 } \\
\text { Campylobacter } \\
(28.4 \%)\end{array}$ & $\begin{array}{l}\text { Not captured by } \\
\text { cultivation }\end{array}$ & $36.7 \%$ & $\begin{array}{l}\text { OTU0032 } \\
\text { Akkermansia } \\
(21.1 \%)\end{array}$ & $\begin{array}{l}\text { Not captured by } \\
\text { cultivation }\end{array}$ & $2.8 \%$ \\
\hline 9.1 & $\begin{array}{l}\text { OTU0003 } \\
\text { Escherichia/ } \\
\text { Shigella }(93.8 \%)\end{array}$ & Escherichia coli & $99.8 \%$ & $\begin{array}{l}\text { OTU0032 } \\
\text { Akkermansia } \\
(16.9 \%)\end{array}$ & $\begin{array}{l}\text { Not captured by } \\
\text { cultivation }\end{array}$ & $11.2 \%$ \\
\hline 9.3 & $\begin{array}{l}\text { OTU0003 } \\
\text { Escherichia/ } \\
\text { Shigella (93.8\%) }\end{array}$ & Escherichia coli & $99.7 \%$ & $\begin{array}{l}\text { OTU0006 } \\
\text { Fusobacterium } \\
(32.8 \%)\end{array}$ & $\begin{array}{l}\text { Not captured by } \\
\text { cultivation }\end{array}$ & $1.7 \%$ \\
\hline 9.4 & $\begin{array}{l}\text { OTU0003 } \\
\text { Escherichia/ } \\
\text { Shigella }(72.8 \%)\end{array}$ & Escherichia coli & $99.7 \%$ & $\begin{array}{l}\text { OTU0002 } \\
\text { Pseudomonas } \\
(91.6 \%)\end{array}$ & $\begin{array}{l}\text { Pseudomonas } \\
\text { aeruginosa }\end{array}$ & $92.3 \%$ \\
\hline
\end{tabular}


529 Table 3: Number of bacterial species or OTUs detected both in urine and open wounds at 530 the same sampling timepoint per resident

531

\begin{tabular}{|c|c|c|c|c|c|c|c|}
\hline & \multicolumn{3}{|c|}{$\underline{\text { Culture Dependant }}$} & \multicolumn{3}{|c|}{ Culture Independent } \\
\hline Resident & $\begin{array}{l}\text { Sampling } \\
\text { timepoint }\end{array}$ & $\begin{array}{l}\text { Urine } \\
\text { (No. } \\
\text { species } \\
\text { detected) }\end{array}$ & $\begin{array}{l}\text { Open } \\
\text { wound } \\
\text { (No. } \\
\text { species } \\
\text { detected) }\end{array}$ & $\begin{array}{l}\text { Number of } \\
\text { species found } \\
\text { in both urine } \\
\text { and wound at } \\
\text { the same } \\
\text { sampling } \\
\text { timepoint }\end{array}$ & $\begin{array}{l}\text { Urine } \\
\text { (No. } \\
\text { OTUs } \\
\text { detected) }\end{array}$ & $\begin{array}{l}\text { Open } \\
\text { wound } \\
\text { (No. OTUs } \\
\text { detected) }\end{array}$ & $\begin{array}{l}\text { Number of } \\
\text { OTUs found } \\
\text { in both urine } \\
\text { and wound } \\
\text { at the same } \\
\text { sampling } \\
\text { timepoint }\end{array}$ \\
\hline 1 & 1 & 1 & 2 & 0 & 5 & 32 & 1 \\
\hline 2 & 1 & 1 & 3 & 1 & 26 & 43 & 8 \\
\hline 3 & 1 & 3 & 3 & 3 & 73 & 79 & 50 \\
\hline 4 & 3 & 2 & 4 & 1 & 9 & 38 & 1 \\
\hline 5 & 1 & 3 & 4 & 2 & 5 & 19 & 2 \\
\hline 6 & 3 & 1 & 2 & 0 & 151 & 163 & 106 \\
\hline \multirow[t]{2}{*}{7} & 1 & 5 & 4 & 1 & 57 & 31 & 13 \\
\hline & 2 & 4 & 4 & 2 & 51 & 29 & 9 \\
\hline \multirow[t]{4}{*}{8} & 1 & 4 & 9 & 2 & 63 & 56 & 19 \\
\hline & 2 & 4 & 10 & 2 & 65 & 61 & 19 \\
\hline & 3 & 3 & 6 & 2 & 71 & 75 & 20 \\
\hline & 4 & 4 & 14 & 3 & 62 & 71 & 19 \\
\hline \multirow[t]{3}{*}{9} & 1 & 2 & 5 & 2 & 11 & 142 & 5 \\
\hline & 3 & 2 & 5 & 2 & 10 & 115 & 4 \\
\hline & 4 & 2 & 7 & 2 & 10 & 164 & 4 \\
\hline
\end{tabular}


Table 4: Frequency of bacterial species by culture-dependent identification in urine, open wound, and both urine and wound

\section{5}

536

\begin{tabular}{|l|c|c|c|}
\hline \multicolumn{1}{|c|}{ Cultivar } & $\begin{array}{c}\text { Urine } \\
\mathbf{n = 1 5} \text { timepoints }\end{array}$ & $\begin{array}{c}\text { Open Wound } \\
\mathbf{n = 1 5} \text { timepoints }\end{array}$ & $\begin{array}{c}\text { Frequency } \\
\text { detected in both } \\
\text { urine and wound } \\
\text { at same sampling } \\
\text { timepoint } \\
\text { (i.e.,. } \mathbf{X} \text { of 15 } \\
\text { timepoints) }\end{array}$ \\
\hline Enterococcus faecalis & 9 & 13 & $9(9 / 15,60 \%)$ \\
\hline Proteus mirabilis & 5 & 7 & $4(4 / 15,27 \%)$ \\
\hline Escherichia coli & 4 & 4 & $4(4 / 15,27 \%)$ \\
\hline Providencia stuartii & 4 & 4 & $4(4 / 15,27 \%)$ \\
\hline Pseudomonas aeruginosa & 3 & 7 & $3(3 / 15,20 \%)$ \\
\hline Citrobacter farmeri & 1 & 1 & $1(1 / 15,7 \%)$ \\
\hline Aerococcus sanguinicola & 4 & 0 & $0(0 / 15,0 \%)$ \\
\hline Aerococcus urinae & 2 & 0 & $0(0 / 15,0 \%)$ \\
\hline Corynebacterium aurimucosum & 2 & 0 & $0(0 / 15,0 \%)$ \\
\hline Acinetobacter baumannii & 1 & 8 & $0(0 / 15,0 \%)$ \\
\hline Staphylococcus aureus & 1 & 5 & $0(0 / 15,0 \%)$ \\
\hline Staphylococcus epidermidis & 1 & 2 & $0(0 / 15,0 \%)$ \\
\hline Citrobacter amalonaticus & 1 & 0 & $0(0 / 15,0 \%)$ \\
\hline Enterobacter asburiae & 1 & 0 & $0(0 / 15,0 \%)$ \\
\hline Klebsiella pneumoniae & 1 & 0 & $0(0 / 15,0 \%)$ \\
\hline Staphylococcus capitis & 1 & 0 & $0(0 / 15,0 \%)$ \\
\hline Corynebacterium striatum & 0 & 7 & $0(0 / 15,0 \%)$ \\
\hline Morganella morganii & 0 & 3 & $0(0 / 15,0 \%)$ \\
\hline Staphylococcus cohnii & 0 & 3 & $0(0 / 15,0 \%)$ \\
\hline Staphylococcus simulans & 0 & 3 & $0(0 / 15,0 \%)$ \\
\hline Arthrobacter cumminsii & 0 & 2 & $0(0 / 15,0 \%)$ \\
\hline Corynebacterium amycolatum & 0 & 2 & $0(0 / 15,0 \%)$ \\
\hline Streptococcus agalactiae & 0 & 2 & $0(0 / 15,0 \%)$ \\
\hline Brevibacterium ravenspurgense & 0 & 1 & $0(0 / 15,0 \%)$ \\
\hline Enterococcus avium & 0 & 1 & $0(0 / 15,0 \%)$ \\
\hline Globicatella sanguinis & 0 & 1 & $0(0 / 15,0 \%)$ \\
\hline Providencia rettgeri & 0 & 1 & $0(0 / 15,0 \%)$ \\
\hline Serratia marcescens & 0 & 1 & $0(0 / 15,0 \%)$ \\
\hline Streptococcus constellatus & 0 & 1 & $0(0 / 15,0 \%)$ \\
\hline Streptococcus mitis & 0 & 1 & $0(0 / 15,0 \%)$ \\
\hline
\end{tabular}


540 Figure 1: Microbial community structure of urine and open wounds in this study. The

541 microbial community structure of urine and open wounds was determined through amplification

542 of the V4 16S rRNA gene followed by Illumina sequencing. Sequence data was processed and

543 analyzed using the software package mothur. Samples were normalized to 7,395 sequences

544 per sample and barplot was visualized using R. In some cases, urine samples were dominated

545 by one OTU, whereas wound samples were more frequently found to be characterized by many

546 species. The $X$-axis identifies the resident and sampling time point (e.g., 1.1 for resident 1 at the

547 first sampling timepoint). The y-axis represents the relative abundance for each OTU. 
bioRxiv preprint doi: https://doi.org/10.1101/614917; this version posted April 22, 2019. The copyright holder for this preprint (which was not certified by peer review) is the author/funder, who has granted bioRxiv a license to display the preprint in perpetuity. It is made available under aCC-BY-NC-ND 4.0 International license.
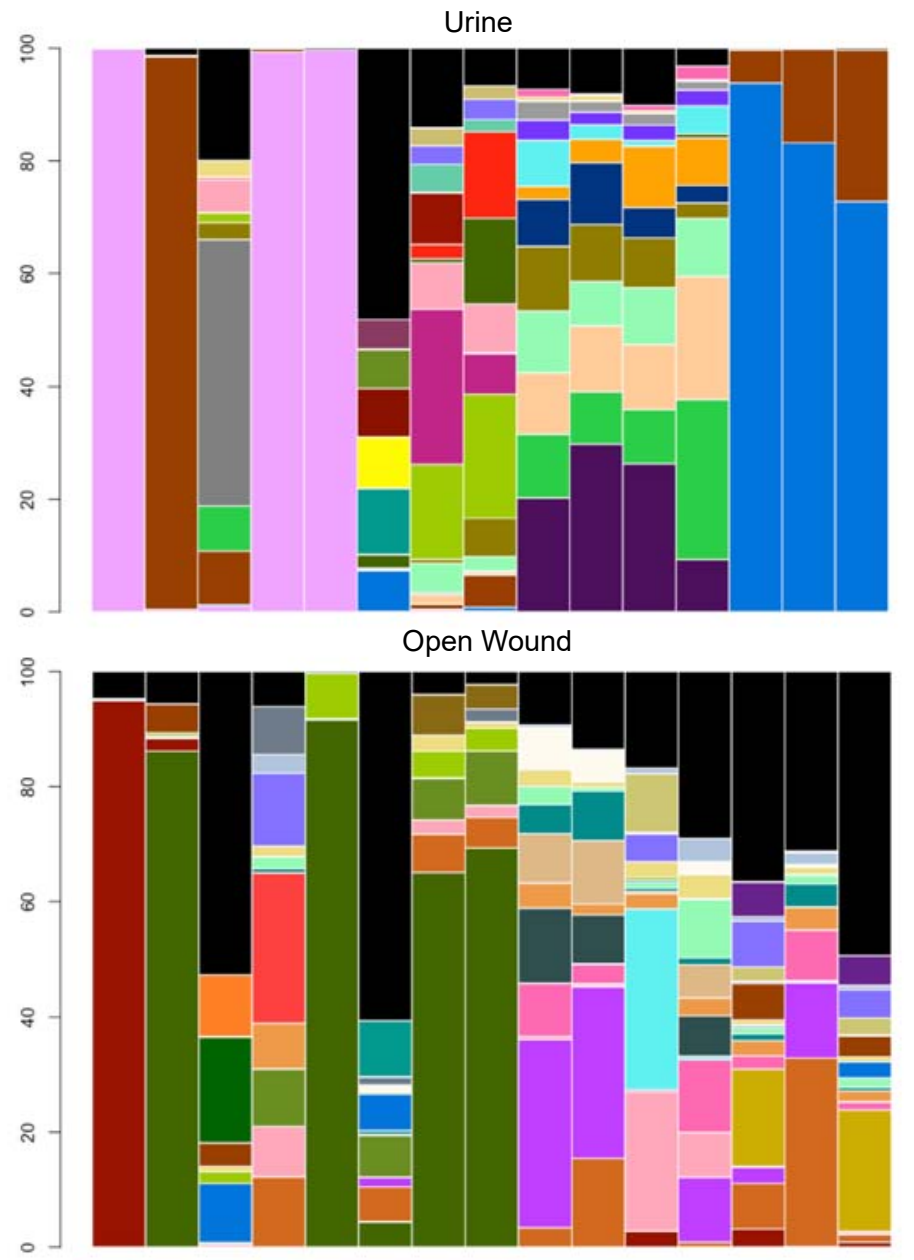

$\begin{array}{lllllllllllllll}1.1 & 2.1 & 3.1 & 4.3 & 5.1 & 6.3 & 7.1 & 7.2 & 8.1 & 8.2 & 8.3 & 8.4 & 9.1 & 9.3 & 9.4\end{array}$

- Unclassified Enterobacteriaceae (Otu0001) - Corynebacterium (Otu0013)

- Pseudomonas (Otu0002)

- Escherichia/Shigella (Otu0003)

- Enterococcus (Otu0004)

- Acinetobacter (Otu0005)

- Fusobacterium (Otu0006)

- Prevotella (Otu0007)

- Finegoldia (Otu0008)

- Staphylococcus (Otu0009)

- Prevotella (Otu0010)

- Parvimonas (Otu0011)

- Streptococcus (Otu0012)

\section{- Providencia (Otu0014)}

- Campylobacter (Otu0015)

- Peptoniphilus (Otu0016)

- Anaerococcus (Otu0017)

- Aerococcus (Otu0018)

Proteus (Otu0019)

- Corynebacterium (Otu0020)

- Actinotignum (Otu0021)

- Unclassified Pasteurellaceae (Otu0022)

- Achromobacter (Otu0023)

- Porphyromonas (Otu0024)
Anaerococcus (Otu0025)

- Porphyromonas (Otu0026)

- Prevotella (Otu0027) Prevotella (Otu0028)

- Peptostreptococcus (Otu0029)

- Streptococcus (Otu0030)

- Bacteroides (Otu0031)

- Akkermansia (Otu0032)

- Peptoniphilus (Otu0034) Gemella (Otu0038)

- Corynebacterium (Otu0039)

- Burkholderia (Otu0040)
- Aerococcus (Otu0041)

- Unclassified Lachnospiraceae (Otu0042)

- Unclassified Aerococcaceae (Otu0043)

- Peptoniphilus (Otu0049)

- Clostridium_XIVa (Otu0050)

- Blautia (Otu0058)

- Fastidiosipila (Otu0064)

- Helcococcus (Otu0066)

- Bifidobacterium (Otu0068)

- Prevotella (Otu0072)

- Porphyromonas (Otu0077)

- Other 